\author{
E. M. Gurbanov, A. A. Akhundova \\ Baku State University, Baku, Azerbaijan
}

\title{
PHYTOECOLOGICAL INDICATORS FOR BIOLOGICAL RECULTIVATION OF SOILS POLLUTED WITH OIL IN THE ABSHERON PENINSULA
}

\begin{abstract}
Phytoecological indicators of polluted soils of Amirov Oil-and-Gas Production Department (Garadag district, Baku) were studied. Phytocenological and biomorphological analysis of flora was done with the aim of further biological rehabilitation of Absheron peninsula. Oil products (black oil, boring waters, etc.) pollution turns the plant cover into a dead mass. Decontamination of soil and rehabilitation of microbial community improve the soil's fertility. Wild and cultured plant indicators may be used in biopurification of the soils polluted with oil products. Sowing of the fodder crops followed by the technical remediation forms the clean areas of higher productivity.
\end{abstract}

Е. М. Гурбанов, А. А. Ахундова

Бакінський державний університет, Баку, Азербайджан

\section{ФІТОЕКОЛОГІЧНІ ІНДИКАТОРИ БІОЛОГІЧНОЇ \\ РЕКУЛЬТИВАЦЇ̈ ЗАБРУДНЕНИХ НАФТОПРОДУКТАМИ ГРУНТІВ АПШЕРОНСЬКОГО ПІВОСТРОВА}

Досліджено фітоекологічні індикатори забруднених грунтів на території Нафтогазовидобувного управління ім. Амірова (Гарадазький район, Баку). Проведені фітоценологічний і біоморфологічний аналізи флори 3 метою подальшої біологічної рекультивації Апшеронського півострова. Показано, що забруднення нафтопродуктами (мазут, шахтні води тощо) призводить до знищення рослинного покриву. Очищення грунтів та відновлення їх мікрофлори підвищують родючисть грунтів. Дикорослі та культурні рослини-індикатори можуть використовуватися для біологічного очищення забруднених нафтопродуктами грунтів. Штучний висів деяких кормових культур після технічної рекультивації дозволяс сформувати відносно очищені території з вищою продуктивністю.

\section{Э. М. Гурбанов, А. А. Ахундова}

Бакинский государственныий университет, Баку, Азербайджан

\section{ФИТОЭКОЛОГИЧЕСКИЕ ИНДИКАТОРЫ БИОЛОГИЧЕСКОЙ РЕКУЛЬТИВАЦИИ ЗАГРЯЗНЕННЫХ НЕФТЕПРОДУКТАМИ ПОЧВ АПШЕРОНСКОГО ПОЛУОСТРОВА}

\begin{abstract}
Изучены фитоэкологические индикаторы загрязненных почв на территории Нефтегазодобывающего управления им. Амирова (Гарадагский район, Баку). Проведен фитоценологический и биоморфологический анализ флоры с целью дальнейшей биологической рекультивации Апшеронского полуострова. Показано, что загрязнение нефтепродуктами (мазут, шахтные воды и др.) приводит к уничтожению растительного покрова. Очистка почв и восстановление их микрофлоры повышают почвенное плодородие. Дикорастущие и культурные растения-индикаторы могут использоваться для биологической очистки почв загрязненных нефтепродуктами. Искусственный высев некоторых кормовых культур после технической рекультивации позволяет сформировать относительно очищенные территории с более высокой продуктивностью.
\end{abstract}

(C) E. M. Gurbanov, A. A. Akhundova, 2009 


\section{Introduction}

As being economic and ecological importance of recultivation, the phytoecological research was conducted in 2007-2008. For this reason the geobotanical description with ecological aspects was done in oil mines' sample plots, phytoecological research was conducted and dominant and subdominant plants were herborizes and of systematized [9; 10]. Sample plots were situated in the territory closed to oil wells of Amirov Oil-and-Gas Production Department (OGPD). The plots were placed along the Korgoz-Gizildash highway (oil wells 1888 and 1889) and to the north of the Lokbatan settlement (oil wells 1803 and 1479). It is from 28 to 200 meters above the sea level. On the basis of phytoecological and floristic research we determined phytocenological peculiarities and ecological and biomorphological indicators of the plants spreading in the studied area.

The soil and vegetation are polluted there with mineralized waters with bitumen substances. The soil is primary grey-brown and covering with black oil. In summer the climate of the territory is hot and dry. Semidesert areas as well as wetlands with hydrophilic plants were found around the studied oil wells. Description of the phytocenoses types, species and phytoecological characteristics are presented below.

\section{Materials and metods}

Materials of this study were collected in the plots of OGPD that is located in the Garadag district of Baku city, Azerbaijan. It is the high-mountain region with polluted soil. Phytocenological and floristic research was conducted according to "Geobotanika" by V. D. Hadjiyev [2], "Flora of Absheron" by I. I. Karyagin [4] and "Flora of Azerbaijan" [9]. The denomination of plants communities was made on the basis of the dominant species concept.

\section{Results and discussion}

"Complex Plan for improvement of ecological situation in Azerbaijan Republic for 20062010" was approved by the Presidential Decree on September 8, 2006. The research of the soils' oil pollution and taking the environmental protection measures were conducted in the frame of the Complex Plan.

The vegetation research and restoration on lands polluted by oil waste in the Absheron peninsula are the urgent problems. We carried out proper research and summarised the flora data in the studied territory (table 1). Phytoecological research was conducted in selected plots of oil mines in the Absheron peninsula, as well as in the territory of exploiting and nonexploiting oil-wells of the mines nos 1 and 2 of Amirov Oil-and-Gas Production Department in the Garadag district. Data obtained are presented in the tables 2 and 3.

Taxonomical characteristics of the plant species in the studied territory

\begin{tabular}{|l|c|c|c|c|}
\hline \multirow{2}{*}{ Families } & \multicolumn{2}{c|}{ Genera } & \multicolumn{2}{c|}{ Species } \\
\cline { 2 - 5 } & number & $\%$ & number & $\%$ \\
\hline Poaceae Barnhart & 5 & 26.3 & 6 & 25.0 \\
\hline Chenopodiaceae Vent. & 6 & 31.5 & 8 & 33.3 \\
\hline Asteraceae Dumort. & 3 & 15.7 & 4 & 16.6 \\
\hline Cyperaceae Juss. & 1 & 5.3 & 2 & 8.3 \\
\hline Papilionacea Giseke & 1 & 5.3 & 1 & 4.2 \\
\hline Tamaricaceae Link & 1 & 5.3 & 1 & 4.2 \\
\hline Plumbaginaceae Juss. & 1 & 5.3 & 1 & 4.2 \\
\hline Zygophyllaceae R. Br. & 1 & 5.3 & 1 & 100 \\
\hline \multicolumn{1}{|c|}{ Total } & 19 & 100 & 24 & \\
\hline \multicolumn{2}{|c|}{}
\end{tabular}


As indicated in the table 1,24 species of the flowering plants compose the floristic composition of the studied area. It includes 8 families and 19 genera, but the families Poaceae (6 species, $25.0 \%$ ) and Chenopodiaceae ( 8 species, $33.3 \%$ ) are prevailing.

Influence of the oil products, oil water and other ecological factors on plant cover in various territories from Lokbatan to Korgoz settlements was studied. The purpose of the research is to describe systematic, ecological (phytocenotic) and bio-morphological indices of plant communities of the areas polluted by oil, and to find interrelationship of saline soils with particular indicator plants and associations.

In the last years, the classification of the soils polluted by oil and mineralized waters in the Absheron peninsula was made, the ecological map was outlined and further practical measures were carried out for the technical rehabilitation.

Observations in the OGPD's exploited oil mines nos 1 and 2 disclosed the soil pollution by the oil products (black oil and others) and harmful influence on the plant cover with consequent turning into a dead mass. It's necessary to improve conditions for microbes influencing the soils fertility [3]. Rehabilitation success of technical and biological measures depends on humidity, moisture reserve in soils, toxic substances, carbonic anhydride, bitumen substances and other factors [1].

Table 2

Ecological characteristics and species of the Oppositifolious Petrosimonia-Camelthorn-Saltwort association (OGPD's oil mine no 1, oil wells 1888 and 1889; and no 3; 15-20.04.2007)

\begin{tabular}{|c|c|c|c|c|c|}
\hline No & Ecomorphs & $\begin{array}{l}\text { Ecological } \\
\text { group }\end{array}$ & $\begin{array}{l}\text { Abundance } \\
\text { (in points) }\end{array}$ & $\begin{array}{l}\text { Layer } \\
\text { (height) }\end{array}$ & $\begin{array}{l}\text { Phenological } \\
\text { stage }\end{array}$ \\
\hline $\begin{array}{l}1 \\
2\end{array}$ & \begin{tabular}{l}
\multicolumn{1}{c}{ Shrubs } \\
Nitraria schoberi L. \\
Suaeda dendroides (C. A. Mev.) Mog.
\end{tabular} & $\begin{array}{l}\text { xerophyte } \\
\text { halophyte }\end{array}$ & $\begin{array}{c}1-2 \\
1\end{array}$ & $\begin{array}{l}\text { I ( }(80) \\
\text { II (60) }\end{array}$ & $\begin{array}{l}\text { Veg. } \\
\text { Veg. }\end{array}$ \\
\hline 3 & \begin{tabular}{|l} 
Subshrubs \\
Salsola dendroides Pall.
\end{tabular} & mesoxerophyte & $3-4$ & II (65) & Veg. \\
\hline 4 & $\begin{array}{c}\text { Dwarf subshrubs } \\
\text { Kalidium capsicum (L.) Ung.-Sternb. }\end{array}$ & halophyte & $1-2$ & III (30) & \\
\hline $\begin{array}{l}5 \\
6\end{array}$ & $\begin{array}{l}\text { Perennial grasses } \\
\text { Alhagi pseudalhagi (Bieb) Fisch. } \\
\text { Aeluropus littoralis (Gouan) Pall. }\end{array}$ & $\begin{array}{l}\text { mesoxerophyte } \\
\text { halophyte }\end{array}$ & $\begin{array}{l}2-3 \\
1-2\end{array}$ & $\begin{array}{l}\text { II (40) } \\
\text { III (10) }\end{array}$ & $\begin{array}{l}\text { Veg. } \\
\text { Flow. }\end{array}$ \\
\hline $\begin{array}{l}7 \\
8 \\
9 \\
\end{array}$ & \begin{tabular}{|l|}
\multicolumn{1}{|c|}{ Annual grasses } \\
Petrosimonia brachiata (Pall.) Bunge \\
Climacopetra crassa (Bieb) Botsch. \\
Gamanthus pilosus (Pall.) Bunge \\
\end{tabular} & $\begin{array}{l}\text { halophyte } \\
\text { halophyte } \\
\text { halophyte }\end{array}$ & $\begin{array}{l}2 \\
1 \\
1\end{array}$ & $\begin{array}{l}\text { III (20) } \\
\text { III (15) } \\
\text { III (10) }\end{array}$ & $\begin{array}{l}\text { Veg. } \\
\text { Veg. } \\
\text { Veg. }\end{array}$ \\
\hline $\begin{array}{l}10 \\
11 \\
12 \\
13\end{array}$ & \begin{tabular}{l}
\multicolumn{1}{c}{ Ephemers } \\
Hordeum leporinum Link \\
Eremopyrum orientale (L.) Jaub. \& Spach \\
Lolium rigidum Gaudin \\
Anisantha rubens $(\mathrm{L})$ Nevski
\end{tabular} & $\begin{array}{l}\text { xerophyte } \\
\text { xerophyte } \\
\text { xerophyte } \\
\text { xerophyte }\end{array}$ & $\begin{array}{c}1-2 \\
1 \\
1 \\
1\end{array}$ & $\begin{array}{l}\text { II (25) } \\
\text { III (20) } \\
\text { III (15) } \\
\text { III (10) }\end{array}$ & $\begin{array}{l}\text { Flow. } \\
\text { Flow. } \\
\text { Flow. } \\
\text { Flow. }\end{array}$ \\
\hline
\end{tabular}

As indicated in the table 2, the plant cover of that association was described around the wells nos 1888 and 1889 of the oil mine no 1 . Dominant species in the association is the saltwort. Species composition numbers 13 plant species. 5 species of them are xerophytes (38.5\%), 6 species are halophytes $(46.2 \%)$ and 2 species are mesoxerophytes (15.3\%). According to the association's life forms analysis and biomorpholgical classification 2 species are shrubs $(15.4 \%), 1$ species $(7.7 \%)$ is a subshrub, 1 species $(15.4 \%)$ - dwarf subshrub, 2 perennial grasses (15.4\%), 3 annual grasses (23.1\%) and 4 species (30.8 \%) are ephemers. 
Ecological characteristics and species of the Salt Cedar-Dutch Rush-Common Reed association (OGPD's oil mine no 2, oil well 1479; and no 4; 15-20.04.2007)

\begin{tabular}{|c|c|c|c|c|c|}
\hline No & Ecomorphs & $\begin{array}{l}\text { Ecological } \\
\text { group }\end{array}$ & $\begin{array}{l}\text { Abundance } \\
\text { (in points) }\end{array}$ & $\begin{array}{l}\text { Layer } \\
\text { (height) }\end{array}$ & $\begin{array}{l}\text { Phenological } \\
\text { stage }\end{array}$ \\
\hline 1 & $\begin{array}{c}\text { Shrubs } \\
\text { Tamarix ramosissima Ledeb. }\end{array}$ & mesophyte & 2 & $\mathrm{I}(170)$ & Veg. \\
\hline $\begin{array}{l}2 \\
3\end{array}$ & \begin{tabular}{|l}
\multicolumn{1}{c}{ Subshrubs } \\
Salsola denroides Pall. \\
Artemisia scoparia Waldast.
\end{tabular} & $\begin{array}{l}\text { mesoxerophyte } \\
\text { xerophyte }\end{array}$ & $\begin{array}{c}1-2 \\
2\end{array}$ & $\begin{array}{l}\text { III (30) } \\
\text { II (70) }\end{array}$ & $\begin{array}{l}\text { Veg. } \\
\text { Veg. }\end{array}$ \\
\hline $\begin{array}{l}4 \\
5\end{array}$ & \begin{tabular}{|l}
\multicolumn{1}{c}{ Dwarf subshrubs } \\
Salsola orientalis S. G. Gmel. \\
Artemisia szowitziana (Bess.) Grossh.
\end{tabular} & $\begin{array}{l}\text { halophyte } \\
\text { mesophyte }\end{array}$ & $\begin{array}{c}1-2 \\
1 \\
\end{array}$ & $\begin{array}{l}\text { II (60) } \\
\text { II (50) }\end{array}$ & $\begin{array}{l}\text { Veg. } \\
\text { Veg. }\end{array}$ \\
\hline $\begin{array}{c}6 \\
7 \\
8 \\
9 \\
10 \\
\end{array}$ & $\begin{array}{l}\text { Perennial grasses } \\
\text { Phragmites australis (Cav.) Trin. } \\
\text { Juncus acutus L. } \\
\text { Juncus littoralis C. A. Mey. } \\
\text { Tragopogon brevirostris DC. } \\
\text { Aster alpinus L. } \\
\end{array}$ & $\begin{array}{l}\text { hydrophyte } \\
\text { hydrophyte } \\
\text { hydrophyte } \\
\text { mesophyte } \\
\text { mesophyte }\end{array}$ & $\begin{array}{c}3-4 \\
2-3 \\
1-2 \\
1 \\
1 \\
\end{array}$ & $\begin{array}{l}\text { I (20) } \\
\text { II (70) } \\
\text { II (40) } \\
\text { III (30) } \\
\text { III (20) } \\
\end{array}$ & $\begin{array}{l}\text { Veg. } \\
\text { Veg. } \\
\text { Veg. } \\
\text { Flow. } \\
\text { Flow. }\end{array}$ \\
\hline $\begin{array}{l}11 \\
12 \\
13\end{array}$ & \begin{tabular}{|l}
\multicolumn{1}{c}{ Annual grasses } \\
Gamanthus pilosus (Pall.) Bunge \\
Salicornia europeaea L. \\
Psylliostachys spicata (Willd.) Nevski
\end{tabular} & $\begin{array}{l}\text { halophyte } \\
\text { halophyte } \\
\text { halophyte }\end{array}$ & $\begin{array}{c}1-2 \\
1 \\
1\end{array}$ & $\begin{array}{l}\text { III (10) } \\
\text { III (15) } \\
\text { III (10) }\end{array}$ & $\begin{array}{l}\text { Veg. } \\
\text { Veg. } \\
\text { Veg. }\end{array}$ \\
\hline $\begin{array}{l}14 \\
15\end{array}$ & \begin{tabular}{l}
\multicolumn{1}{|c|}{ Ephemers } \\
Eremopyrum orientale (L.) Jaub. \& Spach \\
Bromus japonicus Thunb.
\end{tabular} & $\begin{array}{l}\text { xerophyte } \\
\text { xerophyte }\end{array}$ & $\begin{array}{c}1-2 \\
1 \\
\end{array}$ & $\begin{array}{l}\text { III (20) } \\
\text { III (15) }\end{array}$ & $\begin{array}{l}\text { Flow. } \\
\text { Flow. }\end{array}$ \\
\hline
\end{tabular}

The plant cover described around the OGPD's oil mines nos 2 (oil well 1479) and 4 is the salt cedar-dutch rush-common reed association (table 3). Dominant species in the association is the common reed. Species composition numbers 15 plant species: 4 species of halophytes and mesophytes each $(26.7 \%), 3$ species of hydrophytes and xerophytes each $(20.0 \%)$ and 1 species is a mesoxerophyte $(6.7 \%)$. According to the association's life forms analysis and biomorpholgical classification the salt cedar-dutch rush-common reed association consists of 1 species $(6.7 \%)$ of a shrub, subshrubs and dwarf subshrubs - in 2 species (13.3\%) both, 5 species $(33.3 \%)$ of perennial grasses, 3 species $(20.0 \%)$ of annual grasses and 2 species $(13.3 \%)$ of ephemers.

Using scientific-methodological bases of the phytocenology, as applied to our data on phytoecological research, allows determining the sowing rate of plants-indicators and the depth of drilling. The ecological scheme of the plant cover recultivation of the soils polluted by oil has been developed. For the best results the pollution level of soils and vegetation type were taken into consideration (table 4, 5).

Polluted areas of the oil mine no 1 are characterised by the following phytocenotic indicators: first recultivation stage - the shrub Nitraria schoberi, second stage - the subshrub Salsola dendroides and perennial grass Alhagi pseudalhagi, third stage - annual grass Petrosimonia brachiata and other grasses, and ephemers.

The cenotic composition of the oil mine no 2 has been marked by Tamarix ramosissima and Phragmites australis for the first recultivation stage, Juncus acutus - for the second stage, Salsola dendroides and other species - for the third stage. The dominant of the association is $P$. australis, its plenty is 3-4 points, and the subdominants are J.acutus (2-3 points) and T. ramosis (2 points). P. brachiata and halophytes are widely distributed on the polluted saline soils in the studied area and inform that the soils are polluted very harshly. 
Principal phytoecological classification of the soil cover community of area polluted with oil of the oil mines nos 1 and 2 of OGPD is presented below:

1) semidesert: P. brachiata - A. pseudalhagi $-S$. dendrodies;

2) wetlands: $T$. ramosissima $-J$. acutus $-P$. australis.

Our phytoecological field research conducted at the oil mines of Amirov Oil-and-Gas Production Department shows a possibility to carry out biological recultivation following the technical rehabilitation. Literature data describe the recultivation procedure in three stages $[3 ; 6 ; 8]$.

Table 4

Characteristics of the areas polluted by the oil mines waste

\begin{tabular}{|c|c|c|c|c|}
\hline $\begin{array}{c}\text { Pollution } \\
\text { level }\end{array}$ & Source of pollutants & $\begin{array}{c}\text { Contaminating } \\
\text { substances }\end{array}$ & $\begin{array}{c}\text { Ecological } \\
\text { consequences }\end{array}$ & Surface's view \\
\hline Weak & $\begin{array}{c}\text { Boring washed } \\
\text { substances }\end{array}$ & $\begin{array}{c}\text { Bitumen substances, } \\
\text { up to } 1 \%\end{array}$ & Projective & No evidences \\
\hline Medium & $\begin{array}{c}\text { Washed substances, } \\
\text { gas condensate }\end{array}$ & $\begin{array}{c}\text { Bitumen substances, } \\
\text { up to } 2.5 \%\end{array}$ & $\begin{array}{c}\text { Thinning plant cover } \\
\text { (indicators of the sa- } \\
\text { line soil) }\end{array}$ & Whitish brown spots \\
\hline Critical & $\begin{array}{c}\text { Washed substances, } \\
\text { oil }\end{array}$ & $\begin{array}{c}\text { Waters with sulphated and } \\
\text { chlorinated salts } \\
\text { (solid residue }-1 \% \text { ) } \\
\text { Bitumen substances, } \\
\text { up to } 3.7 \%\end{array}$ & $\begin{array}{c}\text { Considerable thinning } \\
\text { of the plant cover }\end{array}$ & Oil spots \\
critical & $\begin{array}{c}\text { Release of strongly } \\
\text { mineralized water } \\
\text { on the surface in case } \\
\text { of accident }\end{array}$ & $\begin{array}{c}\text { Waters with sulphated and } \\
\text { chlorinated salts (solid } \\
\text { residue }-1 \% \text { ) Bitumen sub- } \\
\text { stances, up to 5\% }\end{array}$ & Total death of plants & $\begin{array}{c}\text { Flooding of soil surface } \\
\text { with oil and } \\
\text { mineralized waters }\end{array}$ \\
\hline
\end{tabular}

Sowing rate and the depth of drilling of the main plant indicators proposed for the rehabilitation of different grey-brown soils polluted with oil

\begin{tabular}{|c|c|c|c|c|c|}
\hline \multirow{2}{*}{ Name of plant species } & \multicolumn{2}{|c|}{ Sowing rate } & \multicolumn{3}{|c|}{$\begin{array}{l}\text { Depth of drilling }(\mathrm{cm}) \\
\text { in different soils }\end{array}$} \\
\hline & random & wide rows & $\begin{array}{c}\text { clayey } \\
\text { and loam }\end{array}$ & loam & $\begin{array}{l}\text { sandy and } \\
\text { sandy loam }\end{array}$ \\
\hline Medicago sativa L. & 20 & 9 & 1.5 & 2.0 & 3.0 \\
\hline Glycyrrhiza qlabra L. & 40 & 20 & 2.0 & 3.0 & 4.0 \\
\hline Elytrigia elongatiformis (Drob.) Nevski & 16 & 8 & 1.5 & 2.0 & 3.0 \\
\hline Avena eriantha Durieu & 150 & - & 2.0 & 3.0 & 4.0 \\
\hline Bromopsis riparia (Rehm.) Holub & 35 & 18 & 1.5 & 2.0 & 3.0 \\
\hline Phleum phleoides (L.)Karst. & 25 & 13 & 1.5 & 1.5 & 2.0 \\
\hline Lolium rigidum Gaudin & 16 & 8 & 1.5 & 2.0 & 3.0 \\
\hline Cynodon dactylon (L.) Pers. & 25 & 20 & 1.5 & 2.0 & 3.0 \\
\hline Artemisia scoparia Waldst. & 15 & 8 & 2.0 & 2.0 & 4.0 \\
\hline
\end{tabular}

The stage I is a preparatory work, which should improve aeration and humidity, and decrease the pollution of toxic geochemical environment. The main goal of first measures is to intensify microbiological processes as well as phytochemical and physical breakdown of oil with a subsequent diminishing its thickness on the soil [3].

Sowing is carried out in the stage II in order to evaluate phytotoxic effect in the polluted area, to intensify oil biodegradation processes and to improve agrophysical peculiarities of the soil (table 5). This measure promotes the regulation of acid-base balance, water regime and desalinization. 
Natural plant cover is under restoration in the stage III, grasses presented in the table 5 are experimentally sown and agrophytocenosis is formed. We note that it's possible to use $P$. australis, Typha angustifolia and Trifolium media, and other wild and cultured plants for biological cleaning the soils polluted by oil and regulating humidity.

It's necessary to note that as a result of oil mining, formation of road system and constructions building in Garadag district's lowland a lot of hills and basins formed, humid layer of the soil was taken. The soil, lakes and salt water bodies polluted by oil formed in this area. So, in order to increase rehabilitated lowland's territory it's possible to carry out biological recultivation, to dry formed pools and bogs, to restore plant cover by levelling proper fields and sowing the seeds of fodder crops acclimatazed for local climate-soil conditions. As a result, plant communities of higher productivity developed.

We suggest carrying out the following measures for biological recultivation:

- realization of favourable water supply of the soils;

- study and estimation of agrotechnical, agrochemical and biological land-reclamation measures;

- application of organic and mineral fertilizers in accordance with agrotechnical rules before ploughing.

Thus, biological recultivation carried out in the OGPD's territory located in the Absheron peninsula, agrotechnical and phytoecological measures provide with biologically favourable conditions for the newly recultivated plants. Therefore, it's an actual problem to restore the soil humidity and to rehabilitate the plant cover on lands polluted with oil and mineralized waters. So, biological recultivation measures carried out on the phytoecological scientific base make possible to improve fertility and to restore the plant cover in oil mines' soils in the Absheron peninsula.

\section{References}

1. Askerov F. A. Experiment of recultivation of oil polluted soils in Azerbaijan / F. A. Askerov, N. M. Ismailov // Energy, Ecology, Economy. - Baku, 2001. - N 1 (8-9). - P. 66-72.

2. Hadjiyev V. D. Geobotany in Azerbaijan and its prospects of development // Academy of Sciences of Azerbaijan (Biological Science). - 1979. - No 6. - P. 3-8.

3. Ismailov N. M. Ecological biotechnology in solution of recultivation of oil polluted soil of Absheron peninsula. $\mathrm{PhD}$ thesis. - Baku, 1996. - $41 \mathrm{p}$.

4. Karyagin I. I. Flora of Absheron. - Baku: Academy of Sciences of Azerbaijan, 1952. - 440 p.

5. Novruzov V. S. Ecology of plants (with a basis of Geobotany) / V. S. Novruzov, E. M. Gurbanov, Z. N. Ismayilova. - Baku, 1998. - 197 p.

6. Siradjev A. A. On the prospects of the soil contaminated territory purification in Absheron peninsula // Energy, Ecology, Economy. - Baku, 2001. - No 1.- P. 128-130.

7. Yagubov G. S. The principal aspects of recultivation of oil polluted soils of Absheron / Baku International Congress, 1995. - P. 266.

8. Yagubov G. S. Agrochemical properties of bituminoid soil and their significance in conduction of recultivation work / G. S. Yagubov, N. F. Hakimova, E. A. Baxshiy // Reserves of Azerbaijan's soil and its protection. Azerbaijan Earth Scientists Society. - Baku: Academy of Sciences of Azerbaijan SSR.

9. Flora of Azerbaijan. - Baku: Academy of Science of Azerbaijan SSR, 1950-1961. - Vol. 1-8.

10. Cherepanov S. K. Vascular plants of Russia and adjacent states (the former USSR). - Cambridge: Cambridge University press, 1995. - 992 p.

Надійшла до редколегії 02.07.2009 